\title{
The financial crisis in the German and English press: Metaphorical structures in the media coverage on Greece, Spain and Italy
}

\author{
Hans Bickes, Tina Otten and Laura \\ Chelsea Weymann \\ Leibniz University of Hanover, Germany
}

\begin{abstract}
The German media presentation of the so-called Greek financial crisis caused an unexpected uproar in Germany. An anti-Greek sentiment evolved and spread among German citizens and solidarity for crisis-hit Greece was mostly rejected. Public surveys revealed that many Germans even wanted Greece to exit the Eurozone immediately. This article highlights the crucial role of the media in shaping the negative public opinion. In 2010, a period which has lately been referred to as Greek bashing, the German press had discussed the Greek financial crisis heatedly and controversially. Europe's largest daily newspaper, BILD, published numerous reports that implicitly and explicitly constituted the myth of the corrupt and lazy Greeks in comparison to the hard-working Germans. In 2012, the crisis had spread much further, and not only Greece but other countries too were suffering from high debt, economic stagnation and unemployment. The news coverage became more moderate and conciliating and presented the dramatic social consequences for the respective population. This study highlights not only the development of the German media's tenor on the Greek crisis through time, but adds an international perspective and widens the view by comparing the media treatment of the different countries involved. Based on 122 online articles, the study methodologically focuses on the analysis of metaphorical language in the news coverage of three comparable international news magazines: SPIEGEL (Germany), The Economist (the UK) and TIME (the USA), and contrasts the representation of Greece with the depiction of larger indebted European countries like Spain and Italy. The analysis shows remarkable differences in the evaluation and presentation of the crisis, which can be linked to the degree of involvement of Germany, the UK and the USA in European policies.
\end{abstract}

\section{Corresponding author:}

Hans Bickes, Leibniz University of Hanover, Deutsches Seminar, Königsworther Platz I, D-30167 Hanover, Germany.

Email: hans.bickes@germanistik.uni-hannover.de 


\section{Keywords}

Critical discourse analysis, discourse positions, German/English press, Greek/European financial crisis, media coverage, metaphor analysis

\section{Introduction}

At the end of 2009, Greek Prime Minister Papandreou publicly revised the government deficit, thereby marking the beginning of what is referred to as the Greekfinancial crisis today. It quickly became obvious that the severe crisis which the Greek economy had to face was the result of both internal and external factors - and might even threaten the stability of the euro. Moreover, it seemed clear that Greece did not have the ability to bring its deficit under control without the help of the other Eurozone countries. In return for drastic spending cuts and tax rises, as well as labour market and pension reforms that the European Union (EU) and International Monetary Fund (IMF) insisted on, the Eurozone countries agreed on a rescue package for debt-laden Greece, totalling $€ 110 \mathrm{bn}$. Eventually, Germany approved a $€ 22.4$ bn share of this package. This caused an unexpected uproar and a noticeable anti-Greek sentiment in Germany. Public surveys revealed that many Germans even wanted Greece to leave the Eurozone.

In February 2010, the German magazine FOCUS marked the beginning of an enduring public media campaign in Germany that was characterized by a prominent putting forward of strongly one-sided views and rather rash judgements. The issue's cover presented its readers with a digitally manipulated photo of the Greek goddess Aphrodite giving everyone the finger, accompanied by the front-page headline 'Betrüger in der Euro-Familie' (Betrayers in the Euro-family). The associated article, with the provocative title '2000 Jahre Niedergang. Von der Wiege Europas zum Hinterhof Europas: Griechenlands Abstieg ist beispiellos' (2000 years of decline. From Europe's cradle to Europe's slum area: Greece's descent is unparalleled), arbitrarily compares random characteristics of ancient and contemporary Greece, that is, arts, architecture, education systems, politics and gastronomy. According to FOCUS, a reputable magazine widely considered as serious and reliable, contemporary Greek culture distinctly falls below the level of antiquity in all matters. In addition to the derogatory modification of Aphrodite, an important cultural symbol to the Greeks, the author's references were especially provocative. He refers to the ideology of Jakob Philipp Fallmerayer, an Austrian publicist known for his controversial theories concerning the racial origins of the Greeks, to Oswald Spengler, a German historian who published 'Der Untergang des Abendlandes' (The decline of the West) and who proposes a theory according to which civilizations have a limited life span and ultimately decay, as well as to the Islamic prophet Muhammad. Using metaphors of blooming and withering, the author illustrates Greece's cultural history and ultimately concludes that Greece had its heyday long ago. The article's predominant suggestion is that the supposed decline of Greek culture is the main reason for Greece's disastrous role within the European financial system. Economic considerations of Greece's situation in the wider context of the global financial crisis, as well as differentiating analyses of Greece's history before, during and after the Second World War, are almost completely omitted. On the 
whole, and with far fewer superficial exceptions, FOCUS's treatment of the issue basically offers monocausal explanations for the European financial crisis that lead to the conclusion that Greece has to leave the Eurozone. Due to the use of off-topic arguments, for instance the role of Greek culture and mentality in the European financial crisis, increasingly partisan analyses and a discriminatory, to some extent even racist, use of language, Greece became the centre of focus in the search for reasons for the crisis, although those reasons should have been sought out on a global level and in an economic thinking that is established worldwide.

The beginning of this Greek bashing, as it is referred to nowadays, prompted Greek newspapers and magazines to react. In consequence, a digitally manipulated photo of the statue of Victoria on the Berlin Victory Column was published by the Greek newspaper Eleftheros Typos, showing Victoria raising a swastika as it had been adopted as a symbol of the Nazi Party of Germany in 1920. Other Greek media described contemporary German culture as still being under the influence of Adolf Hitler's spirit. Demonstrators in Athens and Thessaloniki exhibited pictures of Angela Merkel wearing a Nazi uniform.

One may believe that, with such an approach to the topic, the magazine FOCUS was ploughing a lone furrow. However, other influential German newspapers published numerous articles that also tended to construct a lasting negative image of Greece in such a way as to set their German readers against financial aid for a debt-laden Greece. The $B I L D$ in particular, Europe's largest daily newspaper, published plenty of reports that implicitly and explicitly constructed the myth of the corrupt and lazy Greeks in comparison to the hard-working Germans (Otten, 2011). Even reputable political magazines such as the left-wing SPIEGEL shaped a picture of Greece along similar lines.

As a result, many Germans rejected the bailout of Greece and demanded the so-called Grexit. By contrast, a few newspapers, such as the much smaller left-wing and liberal Berlin newspaper taz, tried to pour oil on troubled waters, for instance by trying to prove that Greece was being made a 'scapegoat' for global problems and systemic aspects of the crisis.

Many German newspapers and magazines targeted only one country, however: the small economy of Greece, which was hit first and hardest by the crisis and needed to be bailed out more than once by the euro countries. The hostile and offensive media coverage lasted for about two years. The tenor of Greek bashing weakened somehow towards the end of 2012 and gave rise to a more subtle view on the role of Greece. In 2012, the crisis spread much further and not only Greece, but also Ireland, Portugal, Spain and Italy were deeply involved in financial turmoil. It became obvious that one single country could not be blamed for all economic, financial and political issues (German Council of Economic Experts, 2012). The so-called Greek crisis has developed into a systemic European crisis resulting from structural mistakes of the single currency and additionally intensified by market influences, speculators, the banking crisis and the global financial and economic crisis. Besides Greece, countries such as Ireland, Portugal, Cyprus, Spain and Italy were strongly affected. The crisis of large economies like Spain and Italy became much more dangerous for the Eurozone than the debt burden of little Greece. European bailout money cannot save the two big countries in the case of national bankruptcy. 


\section{Focus of this article/data set}

In order to identify discourse positions during this specific stage of the European financial crisis, we analysed the news coverage of selected media in May, June and July 2012. These three months were chosen due to the high number of events that took place during that time: the first and second Greek elections, the French election, the bailout for Spanish banks, the bailout for Cyprus, the increasing unemployment in Europe, the downgrade of many European countries by rating agency Moody's, etc. We concentrated on investigating and comparing the news coverage of three comparable international news magazines: SPIEGEL (Germany), The Economist (the UK) and TIME (the USA). The three countries were chosen because they represent different perspectives on the crisis. Germany is directly involved in the euro crisis since it shares the single currency and belongs - due to its economic strength - to the leading European countries regarding crisis management. The reputable magazine SPIEGEL was chosen as its attitude towards Greece in the beginning did not essentially differ from discourse positions exposed in BILD and FOCUS (Schendel, 2012). The UK is part of the European Union but not part of the monetary union. We therefore expected a more critical and sceptical perspective from the British magazine. Furthermore, the American magazine was likely to have a more distanced point of view on the European crisis since the USA is not directly involved in it.

We wanted to determine whether the German media stuck to their depiction of Greece and also to contrast the German presentation of Greece and the crisis with the news coverage of other international media. Moreover, the media seemed to take different positions regarding the countries (Greece, Spain, Italy) involved. In short, we pursued the following research questions:

1. Is Greece still presented as the trigger of the crisis or has the tone changed to more sympathy and solidarity?

2. In what respect do the discourse positions of SPIEGEL, The Economist and TIME differ? Is there a significant change in tenor in the German magazine SPIEGEL, compared to the initial phase of Greek bashing?

3. Do the three magazines hold different attitudes towards Greece, Spain and Italy?

4. Who is regarded as offender/victim in the context of the financial crisis?

Our data set consisted of online newspaper articles offering a great variety of easily accessible texts. The articles were selected according to the following criteria:

1. The texts deal with the financial crisis in Greece, Italy or Spain and are intertextually connected.

2. The texts were published in a specific time span (May, June and July 2012).

3. The corpus excludes redundant articles that were equally worded or published twice as well as articles that just touched upon the subject while dealing with another topic.

The focus was on 45 articles per media (15 articles on each of the three chosen countries). In total, 122 online articles served as the corpus for the analysis (Economist and TIME published less than 15 articles dealing with the financial situation in Italy). ${ }^{1}$ 


\section{Method of metaphor research}

Our study is based on the tradition of Critical Discourse Analysis in terms of Foucault, the way it has been used and developed by Wodak, Van Dijk, Fairclough and Chilton, amongst others. Our research questions could effectively be approached by concentrating on instances of metaphorical language. Lakoff and Johnson's well-known Conceptual Metaphor Theory (1980) suggests that metaphors are not just poetic features of language, but that they form, structure and influence human thought. Metaphor is thus central to all processes of perception and 'plays a central role in defining our everyday realities' (Lakoff and Johnson, 1980: 3). Mostly relevant for our purposes of analysis is the Structural Metaphor since it structures abstract concepts with the help of concrete and easily accessible source domains. In other words, the structure of the concrete source domain is used to shape the vague target domain. It hence simplifies its understanding, highlights or hides certain aspects of the target domain and has a big impact on how the abstract concept is conceived. Different source domains go along with different perspectives.

Lakoff and Johnson's theory has been extended by Charteris-Black's (2004) pragmatic approach to metaphor analysis. While Lakoff and Johnson assume that most people are not consciously aware of the metaphorical concepts that structure their perception, Charteris-Black (cf. 2004: 11) argues that speakers use metaphorical concepts purposefully and in a goal-oriented way to persuade and manipulate. Metaphorical concepts thus serve as an instrument to realize rhetoric intentions and hence do not only reflect the metaphorical structure of the mind, but also actively constitute the organization of human thought. Therefore, metaphor analysis can serve as a helpful tool to identify discourse positions. Due to the metaphor's influence on the structuring of human thought, a manipulative use of metaphorical concepts can have great influence on public opinion and the construction of reality. We therefore analyse how abstract concepts like the 'financial crisis', 'high debt', 'economic and political processes' and 'solidarity', amongst others, are metaphorically presented in the newspaper articles and how far these suggested metaphorical concepts propose a certain perspective on social actors and events. First, all metaphorical expressions that could be identified in the articles were inductively collected. Second, superordinated metaphorical categories were generated from the existing data (e.g. 'The financial crisis is a disease'). In order to clarify that specific metaphorical concepts are typical of language use in a community, it is necessary to prove that these categories can be identified in great quantities in authentic texts. Metaphorical categories were only considered in this study if at least 30 metaphorical instances could be identified in the analysed articles. Due to the limited amount of space available, this article focuses on seven selected metaphorical categories. These seven metaphors were chosen as they proved helpful in identifying discourse positions and in addressing our research questions.

The distribution of metaphorical language use is shown in Table 1. The percentage of all metaphorical instances in proportion to the amount of words in the articles is between $6.9 \%$ and $13 \%$, an average of $10.4 \%$. This shows that metaphorical structures occur at a high frequency in all magazines. The only exception is the metaphor usage in TIME with reference to Italy $(6.9 \%)$, which might be due to the fact that only six articles could be 
Table I. The percentage of metaphors in the magazines.

\begin{tabular}{|c|c|c|c|}
\hline & Spain & Italy & Greece \\
\hline SPIEGEL & $\begin{array}{l}\text { I } 396 \text { metaphors } \\
\text { I } 2.42 \text { I words } \\
\text { Percentage of } \\
\text { metaphors: II.2\% }\end{array}$ & $\begin{array}{l}\text { I } 312 \text { metaphors } \\
\text { II.I58 words } \\
\text { Percentage of } \\
\text { metaphors: II.8\% }\end{array}$ & $\begin{array}{l}\text { I } 269 \text { metaphors } \\
\text { I } 2.74 \text { I words } \\
\text { Percentage of } \\
\text { metaphors: } 10.0 \%\end{array}$ \\
\hline The Economist & $\begin{array}{l}\text { I } 381 \text { metaphors } \\
\text { 10.589 words } \\
\text { Percentage of } \\
\text { metaphors: } 13.0 \%\end{array}$ & $\begin{array}{l}605 \text { metaphors } \\
6.357 \text { words } \\
\text { Percentage of } \\
\text { metaphors: } 9.5 \%\end{array}$ & $\begin{array}{l}\text { I50I metaphors } \\
\text { I } 3.132 \text { words } \\
\text { Percentage of } \\
\text { metaphors: II.4\% }\end{array}$ \\
\hline TIME & $\begin{array}{l}\text { II } 72 \text { metaphors } \\
\text { I } 2.176 \text { words } \\
\text { Percentage of } \\
\text { metaphors: } 9.6 \%\end{array}$ & $\begin{array}{l}229 \text { metaphors } \\
3300 \text { words } \\
\text { Percentage of } \\
\text { metaphors: } 6.9 \%\end{array}$ & $\begin{array}{l}\text { 1401 metaphors } \\
\text { I3.610 words } \\
\text { Percentage of } \\
\text { metaphors: } 10.3 \%\end{array}$ \\
\hline
\end{tabular}

analysed in this case. Apart from that, the magazines are quite comparable in terms of their utilization of metaphorical instances.

\section{Selected metaphorical structures in the media coverage on Greece, Spain and Italy in SPIEGEL, TIME and Economist in 2012}

In 2012, the media was still presenting the financial crisis as a serious threat for Europe. Negative developments in particular (e.g. the failure of the first Greek election in May 2012) were accompanied by the intensive use of destructive source domains, such as FIRE, TIDAL WAVES, EARTHQUAKES, DISEASE, DOWNWARD MOVEMENT, etc. These source domains had already been applied to metaphorically shape the drastic dimension of the financial crisis in 2010 (Bickes et al., 2012; Schendel, 2012). They visualize the disruptive power of the crisis and the ultimate danger for Europe:

- $[\ldots]$ the European Union risks becoming like the Titanic, ${ }^{2}$ with most classes of passengers drowning. (Economist, 05.05.12, 'Spain's Woes - Those Sinking Feelings')

- [...] Spain faces the possibility not only of default, but of pulling the entire Eurozone down with it [...]. (TIME, 08.06.12, 'Spain - Euro Crisis: Spain Inches Closer to a Bank Bailout')

- A banking sector poisoned by toxic assets is the primary cause of Spain's current weakness. (TIME, 28.05.12, 'The Vanguard of Disaster')

- But there are other strains worsening Spain's financial health. (TIME, 28.05.12, 'The Vanguard of Disaster')

This type of metaphor implies that all European countries are endangered, not only those in great debt. The use of destruction metaphors spreads fear among readers. In a state of anxiety, the reader is more likely to accept and approve the determined rescue measures of the government. In a scenario in which the Eurozone is about to collapse, all 
action taken seems to be justified to the reader. Furthermore, this panicking news coverage scares stock markets and investors and might cause them to disinvest.

\section{'The financial crisis is a disease'}

The metaphor 'The financial crisis is a disease' shall serve as an example for the type of metaphor mentioned above and will be probed further in the following. The source domain DISEASE emanates from our field of experience and is therefore easily accessible and understandable. The source domain (DISEASE) is transferred to the target domain (FINANCIAL CRISIS).

- IF SPAIN were a patient, the mood in the hospital ward would be tense. Every attempt by local specialists advised by renowned European consultants to treat the sickness brings no more than temporary relief. Even more worrying, the relapses after each dose are happening sooner and sooner. Spain's chances of avoiding intensive care - a full bail-out - are receding to near vanishing-point. (Economist, 28.07.12, 'Spain and the Markets')

- Even if the bleeding is stanched, the question remains: How will Jerez - and Spain - ever return to anything like healthy economies? (TIME, 28.05.12, 'The Vanguard of Disaster')

- Der Patient Italiens muss sich berappeln, denn seine Pleite würde den Rettungsschirm überfordern. (The patient Italy needs to recover as its bust would overstrain the euro rescue fund.) (SPIEGEL, 25.06.12, 'Italiens Premier Mario Monti')

- Doch wird das reichen, um irgendwann wieder vom Tropf der Hilfszahlungen loszukommen und sich selbst wieder am Kapitalmarkt zu finanzieren? (But will that be sufficient to get off the financial aid drip someday and self-finance on the capital market again?) (SPIEGEL, 18.06.12, 'Griechenlands Leiden wird verlängert')

The crisis is conceptualized as a contagious virus which spreads through Europe and threatens the health of all euro countries. The indebted nations are portrayed as already infected and sickly, and the less indebted nations as healthy. The entire Eurozone is also often presented as disease-ridden. The image of a sick Eurozone makes the reader perceive the financial crisis as a pan-European problem and not as single country troubles. The healthy nations try to heal the sick nations with the help of medicine and surgery. Europe's politicians keep arguing about the type of medicine the respective country needs and whether an overdose of austerity measures might kill the patient.

- Therefore, we realize that these policies were the wrong medicine for the crisis; they were shocking, ineffective policies, which led Greek people to face the possibility of a humanitarian crisis. When there is a patient, and you give him medicine, and it only makes him worse, it is not logical to insist on giving him a higher dose of the same medicine. You've got to change the medicine. If we continue taking this austerity medicine, and especially at a higher dose, that's when Greece is going to be forced out of the euro. (TIME, 31.05.12, 'Alexis Tsipras is the Greek Who Makes Europe Tremble')

It is highly questionable whether the Eurozone will recover or die from its disease. The metaphor indicates that the financial crisis is a serious threat for the survival of the monetary union and suggests an extremely negative assessment of the situation. 
Furthermore, the metaphor emphasizes the danger of a continuously spreading disease. Since the direction of the geographical distribution cannot be predicted, the metaphor indicates that each nation is at risk to be infected next.

- So market correlation data cannot predict contagion. (Economist, 16.06.12, 'Economic Epidemiology')

- It is like an airborne virus that can change direction with the wind, and infect countries that least expect it. (Economist, 16.06.12, 'Economic Epidemiology')

It is particularly enlightening to investigate who - in the eyes of the media - is responsible for the outbreak of disease. Overall, the so-called Greek crisis is most often portrayed as the origin of the Eurozone's sickness. The metaphorical virus is presented as if it emanated from Greece and now infects the rest of Europe. The contagion effect of a possible Greek bankruptcy or a Grexit threatens the whole of Europe. It is feared that a Grexit might trigger a series of knock-on effects which make Greece not only the origin of Europe's financial crisis but also of the possible collapse of the single currency.

- The danger was in the possible contagion effect Greece might present if it outright defaulted or bolted from the union. (TIME, 01.05.12, 'Why We Should Worry About Spain's Economic Pain')

- Economic troubles in one country can infect others. Can economic epidemiology predict which countries might fall sick following a Greek exit? (Economist, 16.06.12, 'Economic Epidemiology')

- The greater risk facing Europe's financial system would be if contagion spreads beyond Greece. (Economist, 19.05.12, 'Exodus, Chapter 1')

Besides Greece, Spain too is often depicted as a trigger for the sickness in the financial sector. Italy especially seems to be at risk of being infected. It is striking that Spain's sickness is portrayed as a symptom of the virus that has infected the entire Eurozone, whereas Greece is depicted as the cause, in other words, as a pathogen of the disease.

- Spain's poor public finances, unlike those of Greece, are a symptom rather than the cause of the country's economic woes. (Economist, 02.06.12, 'How to Save Spain')

- Spain's nightmare is a symptom of what is wrong with the entire euro zone. (Economist, 28.07.12, 'The Flight from Spain')

The distribution of metaphorical instances in the three magazines (see Table 2) shows that the metaphor is mostly used with reference to Greece or Spain by The Economist and $T I M E$. Hence, Spain's situation is assessed to be just as serious as that of Greece. Due to the acute banking crisis in Spain, the country is often perceived as a danger for the Eurozone. The lack of liquidity of a big economy like Spain's would use up all of Europe's financial means. This is also reflected in language use in the discourse. Italy, on the other hand, is a country that has not needed any help from the Euro rescue fund so it is perceived as less threatening and hence presented as less sickly by the two Anglophone 
Table 2. Distribution of the metaphor in the magazines: 'The financial crisis is a disease'.

\begin{tabular}{lllc}
\hline & Spain & Italy & Greece \\
\hline SPIEGEL & 36 & 47 & 31 \\
The Economist & 99 & 28 & 114 \\
TIME & 77 & 12 & 79 \\
\hline
\end{tabular}

magazines. Economist and TIME do not regularly use metaphors of illness to describe Italy's situation, but rather focus on the immediate, pressing crisis in Spain and on the long-term crisis in Greece.

SPIEGEL, on the contrary, uses the metaphor most often when referring to Italy and thus presents Italy's economic and financial problems as the ultimate danger for the single currency. The German magazine makes the crisis seem dangerous and provokes fear in the reader. This strategy might be linked to Germany's role in the crisis as the country's share of financial aid to assist indebted countries is highest out of all Europe. If Italy becomes illiquid, much more of German taxpayers' money will be needed to save the single currency. Additionally, the German nation benefits a lot from the single currency. The German worry about Italy is hence based on national self-interest and not on solidarity. The survival of the single currency is of great importance for the German economy. Italy's bankruptcy could lead to the end of the euro, since the country cannot be saved by the euro bailout fund as its economic size is simply too big. For this reason, SPIEGEL uses the metaphor of disease more often when it comes to Italy.

Considering complete results, it is striking that the metaphor of disease is used more often in the Anglophone magazines than in the German media. The Economist portrays the financial crisis as especially threatening as it is metaphorically presented as a contagious illness in high frequency. Therefore, the aforementioned hypothesis, which states that the British magazine is likely to take up a negative and sceptical stance on the monetary union, can be supported according to the data.

\section{'The debtor countries are victims of the financial crisis'}

Metaphors also hint at the media's depiction of victims and offenders in the context of the financial crisis. The indebted nations are frequently presented as weak, helpless nations which cannot help themselves and are therefore dependent on European financial aid:

- Bei der Europäischen Zentralbank (EZB) geht man offenbar davon aus, dass der Hilferuf aus Madrid bald kommen wird. (The European Central Bank (ECB) obviously assumes that Madrid's cry for help will soon come.) (SPIEGEL, 08.06.12, 'Spanien-Krise, Griechen-Wahl')

- Spain cannot escape from this trap by itself. (Economist, 28.07.12, 'The Flight from Spain')

- Italy's debt, at $120 \%$ of GDP, is already higher than the levels at which Greece, Portugal, and Ireland reached out for help. (TIME, 12.07.11, 'Will Italy Bring Down the Eurozone?') 
Table 3. Distribution of the metaphor in the magazines: 'The debtor countries are victims of the financial crisis'.

\begin{tabular}{llrl}
\hline & Spain & Italy & Greece \\
\hline SPIEGEL & 205 & 139 & 126 \\
Economist & 185 & 22 & 106 \\
TIME & 173 & 8 & 128 \\
\hline
\end{tabular}

The frequency and the distribution of the metaphor (see Table 3) shows that even though Greece's financial situation is no doubt the most severe, Spain is mostly presented as 'the number one victim of the crisis' in all analysed media. The Greeks receive less sympathy and solidarity than the Spaniards, although they have been in the worst financial condition for more than two years. This situation might have been caused by the aggressive representation of the Greek crisis as being self-inflicted for the last few years, especially during the period of Greek bashing. Even though the Greeks have been blamed for a number of years, the tone of the media has not yet changed. None of the news magazines explicitly report that the Greek population cannot be blamed for the mismanagement of the politicians, in the same way in which the Spanish people cannot be blamed for their banking and housing crisis.

Moreover, SPIEGEL often presents Germany as a victim of the crisis. The taxpayers are 'suffering' from the high cost of the rescue packages and the government - as one of Europe's leading governments - is reputed to be under much pressure. This position is metaphorically portrayed as Germany carrying a heavy load:

- Die USA, Frankreich, Großbritannien oder Italien fordern, dass die Deutschen noch mehr Finanzlasten schultern. (The USA, France, Great Britain or Italy demand that the Germans shoulder more financial load.) (SPIEGEL, 17.06.12, 'Blitzanalyse zur Griechen-Wahl')

- Und die gesamte Last würden dann Deutschland und Frankreich gemeinsam tragen. Das wäre ökonomischer und politischer Selbstmord. (Germany and France would then carry the entire load jointly. That would be economic and political suicide.) (SPIEGEL, 13.06.12, 'Kurz vor dem Kollaps')

One the one hand, the metaphor stresses Germany's strength and other countries' weakness, but, on the other hand, indicates that Germany is suffering from a heavy load.

\section{'The euro countries are rescuers'}

The well-off, economically strong euro countries, particularly Germany and France, are depicted as rescuers of the countries in distress. This metaphor establishes an image of heroic, good-natured, selfless and generous euro countries showing solidarity and providing billons of euros out of their private capital to clear the debts of the needy and thus help the poor and helpless:

- Spanien soll den Schutz des Rettungsschirms EFSF anfordern - am besten schon am Wochenende. (Spain shall request the protection of the EFSF rescue umbrella ${ }^{3}$ - best if at the weekend.) (SPIEGEL, 04.06.12, 'Spanien soll unter den Schirm') 
- Dieser ständige Rettungsmechanismus soll jene Sicherheit liefern, die alle bisherigen Maßnahmen nicht gebracht haben. (This permanent rescue mechanism shall bring the kind of protection that all previous actions have not.) (SPIEGEL, 04.06.12, 'Spanien soll unter den Schirm')

However, the indebted nations are not simply rescued out of solidarity. The rescue comes with strings attached. The countries commit to a strict austerity programme when they accept European financial aid:

- Die Bedingungen - Rettungsmilliarden gegen Sanierungskurs - seien klar definiert, sagte Söder SPIEGEL ONLINE. (The requirements - rescue billions for financial restructuring - are clearly defined, Söder told SPIEGEL ONLINE.) (SPIEGEL, 04.05.12, 'Sparfrust in Griechenland')

- Spanish lenders taking bail-out money will be subject to European Union (EU) state-aid rules. (Economist, 16.06.12, 'The Spanish Bail-out - Going to Extra Time')

The role of the rescuer implies a dominant position of power. The stronger euro countries and the European Union determine the crisis policy and take control of the governance of other countries. The media do not mention that the euro rescuers have become particularly strong due to the introduction of the monetary union since they benefitted enormously from exporting into other European countries. Germany's economic strength and its high export rate, for instance, contributed to the development of economic imbalances in Europe. Neither do the media point out that the financially strong countries rescue the indebted nations out of self-interest rather than solidarity as the consequences of a euro breakdown would also be devastating for the economically well-off countries. The rescuers care much more about the survival of the single currency than the wellbeing of the struggling nations.

While the German magazine SPIEGEL frequently portrays Europe's leaders emphatically as saviours of the Euro, Economist and TIME are more critical about the actions and decisions of the crisis managers (see Table 4). Angela Merkel's austerity strategy and her reluctance around financial aids and mutual liability are perceived as cold-hearted and barbaric. However, representation of the German chancellor is not thoroughly negative in the international press. SPIEGEL seems eager to present Merkel's political actions in the most positive way. Germany is characterized as merciful, benevolent and goodnatured. Despite a few critical articles, the German magazine generally presents the government and its decisions positively. The country's self-interest in saving the currency is not explicitly mentioned. Economist and TIME do not use the metaphor as frequently as

Table 4. Distribution of the metaphor in the magazines: 'The euro countries and the European Union are rescuers'.

\begin{tabular}{llcr}
\hline & Spain & Italy & Greece \\
\hline SPIEGEL & 62 & 17 & 45 \\
Economist & 24 & 1 & 1 \\
TIME & 13 & 2 & 10 \\
\hline
\end{tabular}


the German magazine, indicating that they perceive the euro countries to be less heroic and good-hearted.

\section{'The financial crisis is a natural disaster'}

When the media sketch the financial crisis by applying the source domain of a natural disaster to it, they stress the destructive power of the crisis and the danger Europe is exposed to. The image of a tsunami breaking in on Europe provokes fear in the reader. These metaphors play with investors' fears, allow them to lose trust in the markets and hence contribute to their worst case predictions becoming reality:

- They're treating it as if it were a hurricane - a natural disaster that no one could control and for which no one is responsible. (TIME, 29.05.12, 'A Banking Scandal Makes the Crisis No Joke')

- Die ökonomische Tsunami-Welle kommt zurück und trifft nach Spanien jetzt Italien. (The economic tsunami wave is coming back and will now hit Italy after Spain.) (SPIEGEL, 12.06.12, 'Es geht abwärts mit Italien')

- Gewinnt er, könnte schon am Montag eine Paniklawine losgetreten werden [...]. (If he wins, an avalanche of panic could be set off on Monday [...].) (SPIEGEL, 15.06.12, 'Drohgebärden und Lockangebote in letzter Minute')

The media metaphorically construct a reality in which the crisis has gained momentum and seems to have become independent. The crisis is referred to as a 'natural disaster' and therefore seems beyond individual responsibility. This metaphor makes the crisis seem like a natural development and denies the responsibility of banks, financial markets, speculators, politicians and governments. The media still avoid naming the responsible social actors and construct a reality in which the single currency suffers from a stroke of fate. In the course of this argument and the interpretation of this metaphor, Greece is no longer blamed for having triggered the crisis. As a natural disaster cannot be defeated by humans, the metaphor also implies a certain powerlessness of the social actors involved. The metaphor makes all political attempts to stop the crisis seem insignificant.

Moreover, the metaphor lays emphasis on the unpredictability of the crisis. The future of the euro does not only depend on the success of a savings policy, but is to a great extent influenced by European banks, the stock market, investors and speculators. These factors can hardly be controlled. Since a natural disaster can hit everyone, even financially secure nations are in danger.

The earthquake metaphor, for instance, a metaphor which can be frequently identified in the language use of The Economist, serves as a concrete example for a natural disaster metaphor:

- Tremors and rumbles - Earthquakes, political and geological, have disoriented Italy. (Economist, 23.07.12, 'Tremors and Rumbles')

- Some contagion may be caused by markets waking up to the possibility that the Eurozone could indeed fall apart. (Economist, 16.06.12, 'Economic Epidemiology') 
Table 5. Distribution of the metaphor in the magazines: 'The financial crisis is an earthquake that divides Europe'.

\begin{tabular}{llcl}
\hline & Spain & Italy & Greece \\
\hline SPIEGEL & 28 & 13 & 11 \\
Economist & 21 & 23 & 26 \\
TIME & 11 & 3 & 36 \\
\hline
\end{tabular}

The focus of the earthquake metaphor lies primarily in the aspect of destruction. It constructs a reality in which the European continent - the European community, figuratively speaking - falls apart. It stresses the instability of the single currency, the tremors splitting and disuniting the European nations, and thus forecasts the looming disintegration of the Eurozone. By using such metaphors, ${ }^{4}$ the media carry little hope for the single currency and stress its disadvantages, dangers and burdens.

Table 5 shows that the frequency of the euro-sceptical metaphor is highest within the British magazine's media coverage. It conveys the critical attitude of the British government towards the integration of the euro by repeatedly alluding to the impending disintegration of the Eurozone. The assumption that The Economist holds a more negative, critical and sceptical attitude towards the single currency can be confirmed, considering the overall analysis. The Economist outlines a calamitous picture of the crisis in its increased use of threatening metaphors.

SPIEGEL and TIME, however, also express their worries about the future of the monetary union (see also Lampropoulou, 2014, on the UK context). While the American magazine considers Greece to be the main catalyst of the shock waves sent through Europe, the metaphor is - surprisingly - most often applied to Spain by the magazine SPIEGEL. The deep cracks within the Spanish economy, the emerging financial holes within the banking system, as well as the growing disagreement of European states concerning the rescue of the Eurozone, seem to draw Germans' attention away from Greece to Spain. The Economist does not significantly distinguish between the single countries, which supports the thesis that the British magazine is more concerned with the volatility of the Eurozone than about single nations.

\section{'The solution for the financial crisis is mechanical repair'}

Moreover, new metaphorical concepts that highlight the complex, systemic character of the crisis could be identified in 2012. As the crisis progresses, the mechanism metaphor becomes established in the language use of the media and marks a change in the news reporting. While the metaphor could hardly be identified in the corpus in 2010, it is now one of the most frequent metaphorical concepts. This is a clear sign that the currency crisis has meanwhile been accepted and understood as a systemic crisis. Therefore, the media portrays a reality in which the errors of the system (single currency/European Union) have to be identified and repaired:

- But after a brief rally in response to the loan package, investors are starting to question the mechanics of the loan - which will be monitored by the so-called troika team of inspectors 
Table 6. Distribution of the metaphor in the magazines: 'The solution for the financial crisis is mechanical repair'.

\begin{tabular}{lccc}
\hline & Spain & Italy & Greece \\
\hline SPIEGEL & 73 & 77 & 111 \\
Economist & 104 & 14 & 110 \\
TIME & 58 & 2 & 108 \\
\hline
\end{tabular}

from the EU, the European Central Bank and the International Monetary Fund - and whether it can really solve Spain's systemic problems, like its shocking $24 \%$ unemployment rate and its slumping housing market. (TIME, 25.06.12, 'World')

European politics and the system of the European monetary union are increasingly described as faulty devices or machines that have to be examined and inspected. The troika, consisting of the EU, European Central Bank (ECB) and IMF, functions as mechanic or inspector and tries to identify mistakes within the system and to fix them. Additionally, these groups maintain the machine and regularly service the mechanisms in progress by offering different suggestions for improving the system of the EU. These suggestions include plain substitutions of certain parts, more extensive structural changes and even a complete renewal of the whole system. Therefore, different suggestions, models, drafts and strategies are developed in order to service the system. It remains unclear what this new and improved system should ultimately look like, but it is certain that a smoothly running mechanism, which is able to meet the challenges of future crises, has to be developed.

Table 6 shows that the mechanism metaphor is most often used in articles about the Greek financial crisis by all magazines. All magazines agree on the fact that there is an urgent need to improve the Greek mechanism of managing the crisis. Economist and TIME see the need for repairs most acutely for Greece and Spain and so far not for Italy. SPIEGEL uses the metaphor most frequently, which shows that maintenance and renewal of the euro system are considered to be most urgent from the German perspective. Extensive use of the metaphor implies that the structure of the single currency is now believed to be the cause of the crisis, instead of the mismanagement of single countries. The metaphor suggests a long-term restructuring or renewal of the system as a solution.

\section{'European policy is a teaching scenario'}

Particularly revealing is the frequent occurrence of the teacher/learner metaphor which supports the constitution of a hierarchical structure in Europe. The source domain of a 'teaching scenario' is used to classify the actors involved in European crisis management. Those Eurozone countries that are financially well situated, due to their strong economy and working reform systems, occupy the position of teacher. Consequently, they function as role models for the heavily indebted countries. The teachers, especially Germany, dictate strict saving conditions, ensure that the countries conform to these requirements and express reprimands and warnings. If a pupil does not obey the rules, $\mathrm{s} /$ he may be expelled from class (the Eurozone). 
The debtor countries function as pupils in the line of this metaphor. The pupils receive instructions from the teachers, have to pass tasks and tests and meet the given schedule. Not all pupils do well: while Ireland appears to be a paragon, Greece behaves disobediently. Spain, which used to be a teachable pupil years ago, now faces difficulties in passing the exam on the financial crisis. Pupils' performances are rated by the rating agency Moody's insofar as they receive grades for their creditworthiness:

- Ireland, often pointed to as a model pupil, has to do more because its primary deficit of $6.7 \%$ of GDP last year was considerably higher than Greece's and Portugal's. (Economist, 12.05.12, 'The Threat of a Greek Exit')

- Die junge Demokratie [Spanien] wurde in den achtziger Jahren in die Nato und in die EG eingebunden, ein gelehriger Schüler, ein europäischer Musterknabe. (The young democracy [Spain], a teachable pupil, a European paragon, was incorporated into Nato and the EG in the 1980s.) (SPIEGEL, 30.07.12, 'Brandstifter Nr. 1')

- Spanien hat den Test nicht bestanden. (Spain has not passed the test.) (SPIEGEL, 19.06.12, 'Spanien taumelt Richtung Pleite')

- Spanien und Zypern bekommen schlechtere Noten. (Spain and Cyprus get worse grades.) (SPIEGEL, 13.06.12, 'Moody's stuft Spanien und Zypern herab')

The depiction of the indebted countries as students clearly indicates that they are inferior to the financially strong European countries, which are presented as teachers in context of the metaphor. This language use establishes the picture of a divided Europe. The teachers serve as role models and patronize and discipline the debtor countries. The students have to follow the instructions and accept the control of their national budgets and thus lose sovereignty to a certain extent. The establishment of a hierarchical structure in Europe might lead to a dismissive attitude in the non-critical reader towards the peripheral countries (see e.g. user feedback in numerous online media).

The following statement shows The Economist's critical attitude towards the behaviour of Europe's ruling political class and its treatment of Greece. It criticizes attempts to dictate to Greek politicians how to govern their country and to patronize the Greek population with respect to their election:

- I'm against this way of dealing with Greece, [which consists] in provoking the Greek public opinion and giving advice and indications to the Greek sovereign. We don't have to lecture Greece. (Economist, 15.05.12, 'Groping towards Grexit')

In comparison to other metaphors of the corpus, the teacher/learner metaphor was not used frequently (see Table 7). Most commonly, the metaphor occurred in contexts related to Greece, since Greece was mostly patronized by the other Eurozone countries. SPIEGEL and Economist often use the metaphor with reference to Spain, indicating that they see Spain as some kind of problem student.

\section{Conclusion}

The initial phase of Greek bashing in 2010/2011, when Greece and its role within the European financial crisis were depicted in an indecently harsh and aggressive manner, 
Table 7. Distribution of the metaphor in the magazines: 'European policy is a teaching scenario'.

\begin{tabular}{lllc}
\hline & Spain & Italy & Greece \\
\hline SPIEGEL & 12 & 5 & 16 \\
Economist & 10 & 1 & 8 \\
TIME & - & 2 & 1 \\
\hline
\end{tabular}

was accompanied by public demands for a Grexit. Compared to the start of the crisis in 2010, a considerable change took place in 2012 when the tone generally became more moderate and less offending. The debt-burdened countries, and especially their population, receive much more sympathy as the crisis progresses and the attention of the audience is often drawn to the suffering of those in the crisis-hit countries. The magazines tell stories of individual fates and personal tales of woe; they tell stories of poverty, unemployment, job hunting and desperation, thus contrasting this with the earlier picture of lazy, unproductive southern Europeans enjoying siestas and early retirement. The media try to convey the message that these people are suffering from politicians' mistakes, the banking crisis and economic stagnation.

We have analysed and critically compared and contrasted the presentation of three indebted countries - Greece, Spain and Italy - in the media. We aimed at identifying differences in discourse positions towards the three selected countries and at pointing out differences between the three magazines. Investigation of metaphorical language use shows that presentation of the three countries differs. To sum up: there is a tendency rather simplified - to think that Greece comes off worse than Spain and that Spain's condition is worse than Italy's. The harsh tone of the media against Greece has softened to a certain extent since it is not only Greece, but also many other European countries that are suffering from the crisis. Nevertheless, Greece is still assigned a special position in terms of having triggered the crisis in the first place and being a financial burden on the other European nations. It may be concluded that the persistent depiction of the Greek crisis as being self-inflicted by the German media has contributed greatly to this result. After pillorying the Greeks for years, the tenor of the public news coverage does not fundamentally change. While the metaphor 'The financial crisis is a disease' suggests that the dangerous sickness that threatens the whole of Europe originated in Greece, further affected countries like the large economies of Spain and Italy are depicted as infected countries only. The metaphor 'Debtor countries are victims of the financial crisis' also reveals that Spain and Italy are portrayed as victims of the crisis rather than as offenders. The metaphor is greatly classifying insofar as the euro countries are divided into two categories: the financially well-situated countries on the one hand and the indebted countries on the other. While the media present Greece as thoroughly dependent on the financially strong European countries and obvious doubts about a quick Spanish recovery can be identified, they seem to have more confidence in Italy. The large economy of Italy is thought to be capable of surviving the crisis by its own efforts. Despite political crisis, high debt and economic stagnation, Italy and its former assertive Prime Minister Monti are still perceived as self-determined and independent. TIME and 
Economist, especially, trust the country to help itself. For Greece, on the other hand, there seems to be little hope of recovery. However, Spain is also more and more perceived as a danger to the euro countries. The Spanish sickness puts the large national economy of Italy at risk. A bankrupt Spain would eat up European financial aid resources completely and clearly place the euro countries in dire straits.

The discourse positions of the three magazines, which can be shown by metaphor analysis, differ in some important aspects. It is impossible to determine a certain discourse position for each news magazine as they all cover the news relatively differently and take up ambiguous positions. However, the analyses revealed some characteristic tendencies. The magazine SPIEGEL depicts the crisis in a similar fashion to the majority of the German media. It plays with readers' fears of a possible Eurozone breakdown in order to justify Merkel's political actions. Frequent use of the metaphor 'The euro countries are rescuers' makes Germany and its political leaders appear in a good light. SPIEGEL still tries to shift the blame for the crisis away from Germany and often assigns the country heroic-like attributes. The economically weaker countries are dependent on the strong and flourishing German nation. In consequence, the readers of SPIEGEL are likely to develop a self-righteous and arrogant self-perception that deepens the gap between the European north and south, that is, the solvent countries and the financially weak periphery. However, the magazine also criticizes the high financial load on German taxpayers. In general, SPIEGEL's news coverage is much more moderate and less inflammatory than in spring 2010. Occasionally, there are demands for solidarity, even though these remarks are addressing Spain rather than Greece. This result shows how the relationship between Greece and Germany has worsened over the years.

The metaphorical language use in the British magazine The Economist indicates a persistent sceptical attitude towards the single currency and leaves no doubt that the basic principles of the European Union, rather than those of a single country, have to be questioned. The news coverage of The Economist may be characterized by the increasing use of threatening metaphors that draw an especially sinister picture of the financial crisis. The future of the monetary union is approached with scepticism and there are numerous references to the volatility of the common currency, as well as to the impending disintegration of the Eurozone. With regards to the news coverage of The Economist, the crisis has taken on a dramatic turn and cannot be suspended by European financial measures. As a result, The Economist criticizes the European Union and the crisis management of European politicians. In consequence, attention is primarily focused on the risks and negative aspects of being a member of the monetary union. The magazine does not only take sides with the suffering population, but also defends the Greek government by explicitly criticizing the condescending, dominant and patronizing behaviour of European leaders towards Greece.

Metaphorical categories that could not be presented here highlight that TIME tends to take a more distanced perspective. The magazine presents the crisis, for instance, metaphorically as a game which indicates that the crisis is not assessed as an ultimate danger. In its position as an outsider, the American magazine presents itself mostly at a distance, neutral and less emotional when it comes to the European community. Furthermore, the excessive use of war metaphors suggests that bellicose strategies govern American processes of political interaction rather than acts of solidarity. The general use of war 
metaphors indicates that the interaction of the European countries is belligerent and strategic and clearly not that of a solidly united community.

From different analyses in the field of discourse analysis it can be seen that metaphors with disruptive source domains are continuously identifiable over the years and thus shape the fiscal discourse of the European crisis (cf. Bickes et al., 2012; Weymann, 2012). These metaphors reveal that the financial crisis and especially its continuous spread are still considered an immense danger - even two years after the start of the crisis.

Different metaphors highlight the internal dynamics of the crisis: source domains like a natural disaster, a virus, a downward movement, a spreading substance, a tidal wave or a fire imply that the crisis is beyond human control. Consequently, these metaphors lay emphasis on the natural evolution of the crisis. Even though the media no longer blame a single country for all the financial burdens, they still avoid naming the responsible social actors, such as banks, financial markets, speculators, etc. The media construct a reality in which the European monetary union falls victim to some kind of superior power. Instead of identifiable actors, fate seems to be the guiding principle of crisis.

New metaphorical concepts like the mechanism metaphor stress the systemic character of the crisis by identifying the construction of the European Union as the main cause of the crisis. These new metaphors are solution-oriented and suggest a reformation or renewal of the system. Metaphors like the teacher/learner metaphor intensify the formation of a hierarchically divided Europe. Due to the fact that the different European countries are not represented as equal nations, there is an unwelcome chance that the readership of the financially well-situated countries will develop a condescending attitude towards the periphery. Moreover, Euro-sceptic metaphors like the earthquake metaphor highlight the instability of the monetary union and predict the disintegration of the Eurozone.

At the time of writing, approaching the end of 2013, there is a noticeable tendency to tone down the demands for a Grexit. Even so, a phase of Grecovery, such as the recovery of Greece's public image in the form of some kind of countermovement to the Greek bashing, has yet to begin.

\section{Funding}

This research received no specific grant from any funding agency in the public, commercial or not-for-profit sectors.

\section{Notes}

1. The presented results are based on different studies and large-scale analyses of hundreds of articles published by several newspapers and magazines, each working with a specific corpus. These studies are part of a main project which analyses news coverage, mostly in German, but also in Greek, British and American online and print media since 2010. Outcomes have been published in Bickes et al. (2012), Schendel (2012) and Bickes and Otten (2013). Detailed results can moreover be found in some Bachelor and Master's thesis (Otten, 2011; Steinhof, 2012; Weymann, 2012, 2013). Due to the limited amount of words, the outlines given below solely focus on selected results.

2. In the following, all metaphorical instances in the quotations are highlighted in bold.

3. This is a German term for 'Eurozone bailout fund'.

4. This article cannot present complete results, but just a few chosen examples. 


\section{References}

Bickes H and Otten T (2013) Griechenland und die deutschen Medien [Greece and the German media]. Hellenika. Jahrbuch für griechische Kultur und Deutsch-Griechische Beziehungen [Hellenika. Yearbook for Greek Culture and German-Greek relations]. Neue Folge 8: 10-36.

Bickes H, Butulussi E, Otten T, et al. (2012) Die Dynamik der Konstruktion von Differenz und Feindseligkeit am Beispiel der Finanzkrise Griechenlands: Hört beim Geld die Freundschaft auf? Kritisch-diskursanalytische Untersuchungen der Berichterstattung ausgewählter deutscher und griechischer Medien [The dynamics of constructing difference and hostility drawing on the Greek financial crisis: Does friendship and money go together? Critical analyses of the news coverage of selected German and Greek media]. Munich: Iudicium Verlag.

Charteris-Black J (2004) Corpus Approaches to Critical Metaphor Analysis. New York: Palgrave Macmillan.

German Council of Economic Experts (2012) After the Euro Area Summit: Time to Implement Long-term Solutions. Special Report, 30 July. Wiesbaden: German Council of Economic Experts.

Lakoff G and Johnson M (1980) Metaphors We Live By. Chicago, IL/London: University of Chicago Press.

Lampropoulou S (2014) 'Greece will decide the future of Europe': The recontextualisation of the Greek national elections in a British broadsheet newspaper. Discourse \& Society 25(4): 467-482.

Otten T (2011) Solidarität oder Ablehnung? Die Finanzkrise Griechenlands als Krise einer Freundschaft: Eine diskursanalytische Untersuchung der deutschen Medienberichterstattung am Beispiel der BILD und der taz [Solidarity or rejection? The Greek financial crisis as a crisis of friendship. A discourse analytical examination of German media reports by BILD and taz]. Master's thesis, Leibniz University of Hanover, Hanover.

Schendel J (2012) Milliardenspritzen, taumelnde Krisenstaaten und die Hüterin der deutschen Euros: Der Metapherngebrauch im Diskurs um die Schuldenkrise Griechenlands [Injections of billions, reeling crisis states and the guardian of German Euros. The usage of metaphors in the discourse on Greece's financial crisis]. Sprachreport 3: 2-9.

Steinhof A (2012) Diskursive Konstruktion Griechenlands vor dem Hintergrund der europäischen Finanzkrise am Beispiel des FOCUS. Master's thesis, Leibniz University of Hanover, Hanover.

Weymann LC (2012) Kritische Diskursanalyse deutscher Printmedien zum Thema europäische Finanzkrise: Einsatz und Wirkung von Metaphern in ausgewählten Texten [A critical discourse analysis of German print media reporting on the European financial crisis - the usage and impact of metaphors in selected texts]. Bachelor's thesis, Leibniz University of Hanover, Hanover.

Weymann LC (2013) Zwischen Entrüstung, Anschuldigung, Besorgnis und Solidarität: Die Berichterstattung zur Euro-Krise in ausgewählten deutschen, britischen und amerikanischen Medien - eine kritische Diskursanalyse [Between indignation, accusation, concern and solidarity. Reporting on the Euro Crisis in selected German, British and American media - a critical discourse analysis]. Master's thesis, Leibniz University of Hanover, Hanover.

\section{Author biographies}

Hans Bickes studied Philosophy, German Language and Literature, Sports and Psychology at Heidelberg University, Germany, where he received his Dr Phil. in Linguistics. Over the years, he has been a lecturer at Aristoteles University of Thessaloniki, Greece, a managing director of the Society for German Language (Wiesbaden, Germany) and Professor for Communication Studies at the Institute of Technology, Darmstadt, Germany. He is currently Professor of German 
Linguistics at Leibniz University of Hanover, Germany. He has had guest lectureships in Milan, Bologna, Thessaloniki, Seville and Posen. His research areas include language acquisition, German as a foreign or second language, language and cognition, and discourse analysis.

Tina Otten graduated in German Language and Literature, English Language and Literature and Biology at Leibniz University of Hanover, Germany (BSc 2009, M.Ed. 2011). She is currently a research assistant in the Department of German Language at Leibniz University of Hanover, Germany, and is working on her doctoral dissertation. Since 2010 she has been a member of a joint research project analysing the Greek financial crisis (Aristoteles University of Thessaloniki, Greece, and Leibniz University of Hanover, Germany). Her main research areas are applied linguistics, didactics and critical discourse analysis.

Laura Chelsea Weymann studied German and English Language and Literature at Leibniz University of Hanover, Germany (BA 2012, M.Ed. 2013). Since 2010 she has been a member of a joint research project analysing the Greek financial crisis (Aristoteles University of Thessaloniki, Greece, and Leibniz University of Hanover, Germany). Her main research area is critical discourse analysis. 


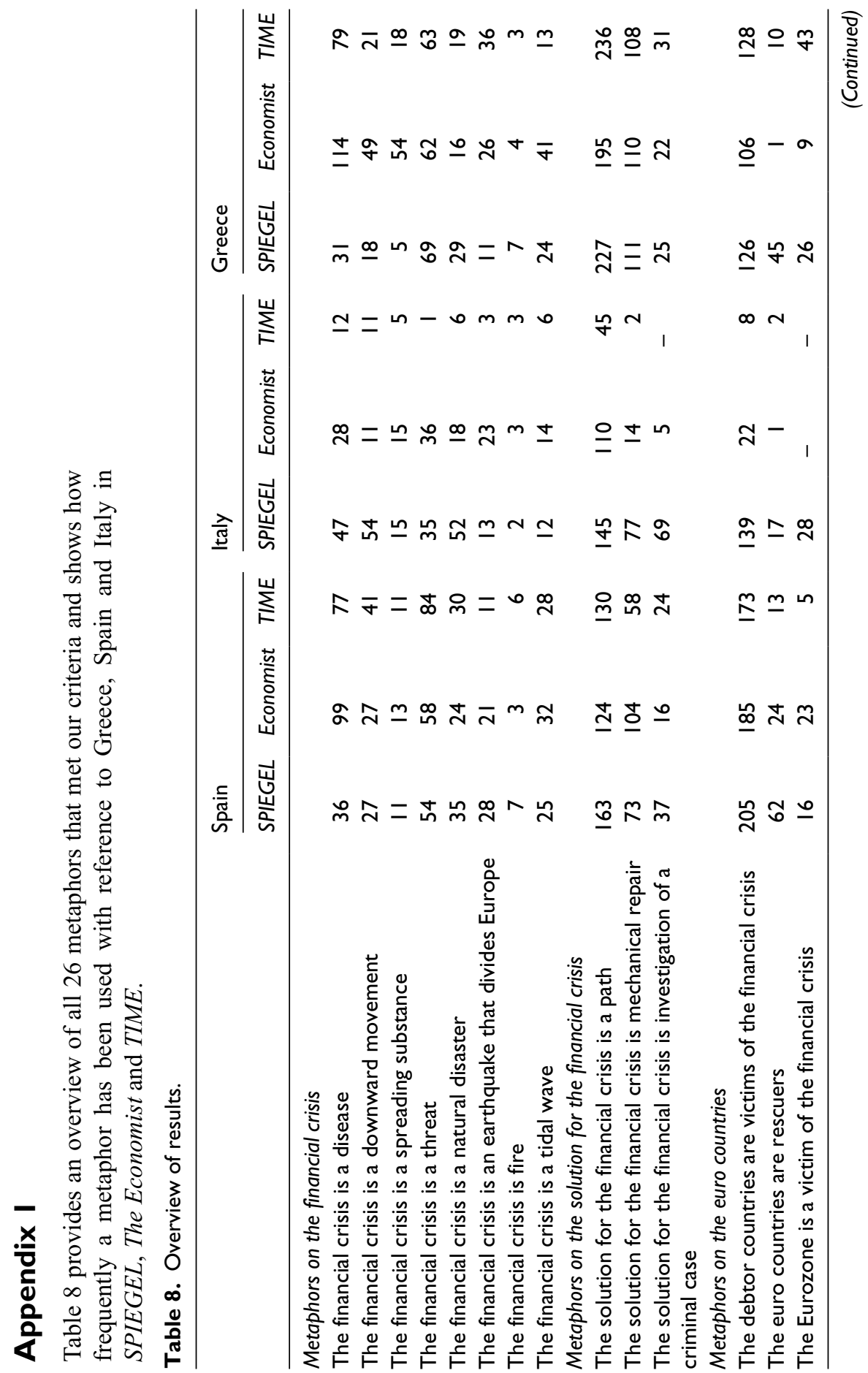




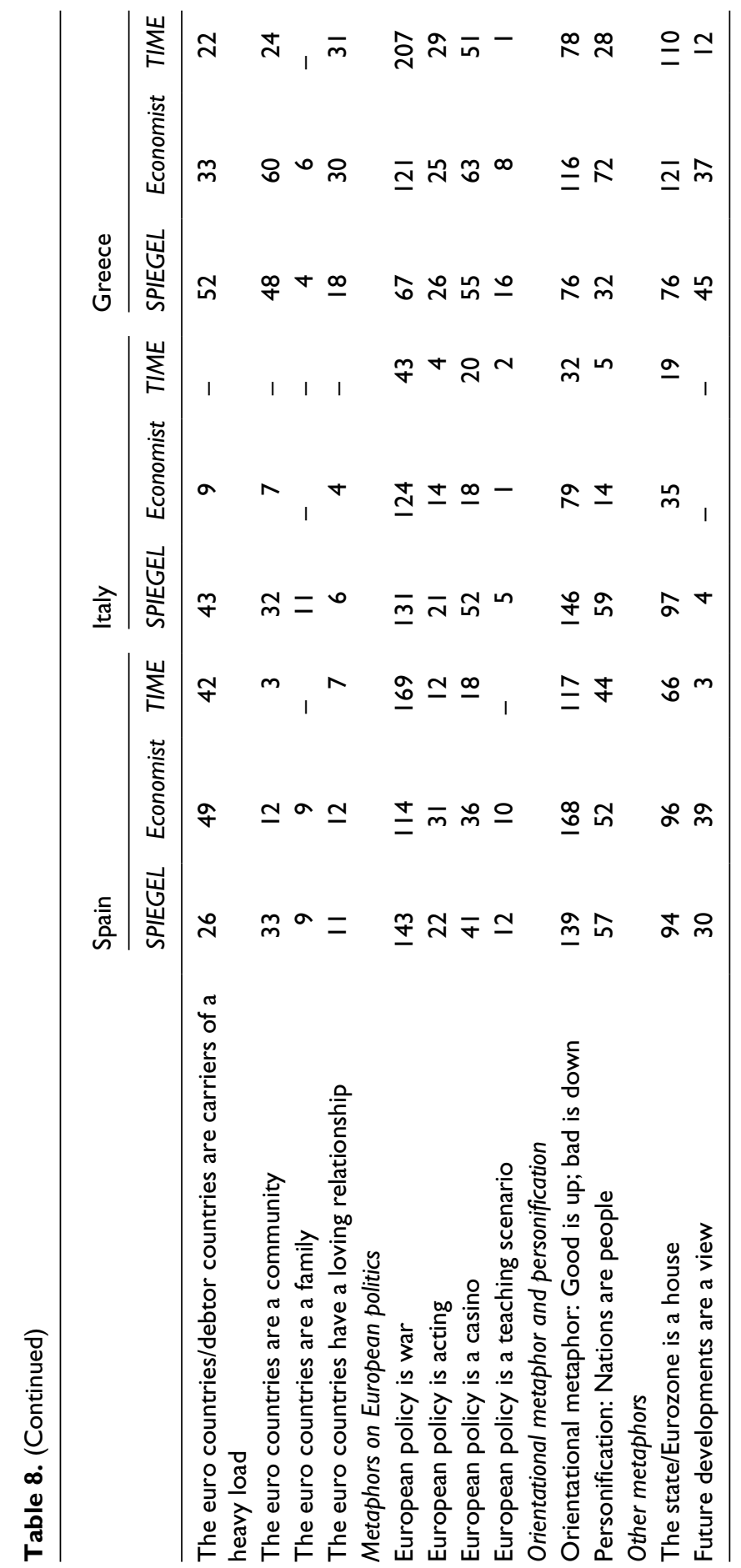

